\title{
Adrenal incidentaloma: a case of carcinoma
}

This article was published in the following Dove Press journal:

Clinical Interventions in Aging

24 February 2010

Number of times this article has been viewed

\author{
Giovanni Ruotolo' \\ Maria Raffaella Ambrosio 5 \\ Patrizia Rosa Caroleo' \\ Elvira Bonacci' \\ Anna Maria Condito ${ }^{2}$ \\ Alfonso Merante' \\ Pierpaolo Arcuri ${ }^{3}$ \\ Bruno Jim Rocca ${ }^{5}$ \\ Bianca Virginia Palermo ${ }^{4}$ \\ Saverio Palermo ${ }^{4}$ \\ Pietro Gareri ${ }^{6}$ \\ 'Head Physician Geriatric Unit, \\ ${ }^{2}$ Emergency Medicine Unit, ${ }^{3}$ Division \\ of Radiology, ${ }^{4}$ Nuclear Medicine \\ Unit, "Pugliese-Ciaccio" Hospital, \\ Catanzaro, Italy; ${ }^{5}$ Department of \\ Human Pathology and Oncology, \\ Pathological Anatomy Section, \\ University of Siena, Siena, Italy; \\ ${ }^{6}$ Elderly Health Care, ASP Catanzaro, \\ Catanzaro, Italy
}

Correspondence: Pietro Gareri Elderly Health Care, ASP Catanzaro, Via Spasari, 3, 88100 Catanzaro, Italy $\mathrm{Tel}+390961721214$

Fax +390961725095

Email pietro.gareri@alice.it

\begin{abstract}
Adrenal incidentaloma (AI) is a term applied to an accidentally discovered adrenal mass on imaging performed for reasons unrelated to adrenal pathology. The widespread application of abdominal imaging procedure has resulted in an increased frequency of clinically silent adrenal masses. Although most AIs are nonfunctioning benign adenomas, a multidisciplinary approach with biochemical and radiological evaluation is needed to characterize these lesions and identify patients who are at high risk for hormonal or malignant evolution. Herein, we describe a case of a 69-year-old man with a pain at the base of right chest. On the basis of clinical evaluation, biochemical analysis, as well as imaging procedures, a diagnosis of right adrenocortical carcinoma was made. The patient underwent medical treatment.
\end{abstract}

Keywords: adrenal incidentaloma, adrenal mass, adrenocortical carcinoma

\section{Introduction}

The widespread use of imaging, particularly computed tomography (CT) and magnetic resonance imaging (MRI), during diagnostic testing or treatment for many clinical conditions, has resulted in the identification of previously unsuspected adrenal lesions defined as adrenal incidentalomas (AIs). ${ }^{1,2}$ The assessment of AIs is aimed at deciding whether or not the tumor should be surgically removed, ${ }^{3}$ adrenalectomy being indicated in hormonal hypersecretory states (such as pheocromocytoma) and in potentially malignant lesions. ${ }^{4}$

Adrenal cortical carcinoma (ACC) is a rare and heterogeneous malignancy with incompletely understood pathogenesis and poor prognosis. ${ }^{5} \mathrm{ACC}$ can be functional or nonfunctional with regard to hormone synthesis and clinical features.

We report the case of a 69 -year-old man who was investigated for chest pain, with a right adrenal carcinoma identified by total body CT-scan and adrenal scintigraphy.

\section{Case report}

A 69-year-old male was admitted to the Geriatric Unit of Catanzaro Hospital due to the onset of chest pain since few days, without other symptoms. Clinical examination and review of systems as well as family medical history were unremarkable. On clinical examination we found only a mild hepatomegaly and a reduction of vesicular murmur. In the past medical history, he reported a moderate increase of systolic and diastolic blood pressure which was controlled by weight reduction, salt restriction, and pharmacological therapy (ramipril plus hydrochlorothiazide $5 / 25 \mathrm{mg}$ one tablet/day). In the present admission, blood pressure was $140 / 80 \mathrm{mmHg}$ and heart rate 110 beats 
per min (bpm); patient's body mass index was $36.36 \mathrm{Kg} / \mathrm{m}^{2}$. Chest X-ray was negative and electrocardiogram (ECG) recorded a sinus tachycardia. Biochemical analyses were normal (Table 1) as well as hormonal evaluation (Table 2). We found only high levels of fibrinogen $(697 \mathrm{mg} / \mathrm{dL})$, lactate dehydrogenase (LDH; $758 \mathrm{U} / \mathrm{L}), \alpha_{2}$-globulins $(8.2 \%)$ (Table 1).

Table I Biochemical evaluation

\begin{tabular}{|c|c|c|}
\hline & & NV \\
\hline RBC & $4.2 \times 10^{6} / \mathrm{mm}^{3}$ & $4.15-4.9 \times 10^{6} / \mathrm{mm}^{3}$ \\
\hline $\mathrm{MCH}$ & 30 pg/cell & $28-33 \mathrm{pg} / \mathrm{cell}$ \\
\hline $\mathrm{MCHC}$ & $34 \mathrm{~g} / \mathrm{dL}$ & $32-36 \mathrm{~g} / \mathrm{dL}$ \\
\hline MCV & $88 \mu \mathrm{m}^{3}$ & $86-98 \mu \mathrm{m}^{3}$ \\
\hline HCT & $44 \%$ & $42 \%-52 \%$ \\
\hline Hemoglobin & $15 \mathrm{~g} / \mathrm{dL}$ & $13-18 \mathrm{~g} / \mathrm{dL}$ \\
\hline WBC & $4.5 \times 10^{3} / \mathrm{mm}^{3}$ & $4.3-10.8 \times 10^{3} / \mathrm{mm}^{3}$ \\
\hline $\mathrm{N}$ & $50 \%$ & $45 \%-75 \%$ \\
\hline L & $20 \%$ & $16 \%-45 \%$ \\
\hline M & $5 \%$ & $4 \%-10 \%$ \\
\hline $\mathrm{E}$ & $2 \%$ & $0 \%-7 \%$ \\
\hline B & $1 \%$ & $0 \%-2 \%$ \\
\hline Albumin & $50 \%$ & $50 \%-60 \%$ \\
\hline$\alpha$ I-globulins & $5 \%$ & $4.2 \%-7.2 \%$ \\
\hline$\alpha 2$-globulins & $8.2 \%$ & $6-7.8 \%$ \\
\hline$\beta$-globulins & $11 \%$ & $9.3 \%-15 \%$ \\
\hline$\gamma$-globulins & $15 \%$ & $13 \%-23 \%$ \\
\hline AST & $20 \mathrm{U} / \mathrm{L}$ & $0-35 \mathrm{U} / \mathrm{L}$ \\
\hline ALT & $24 \mathrm{U} / \mathrm{L}$ & $0-35 \mathrm{U} / \mathrm{L}$ \\
\hline Total bilirubin & $\mathrm{l} \mathrm{mg} / \mathrm{dL}$ & $0.3-1.0 \mathrm{mg} / \mathrm{dL}$ \\
\hline Direct & $0.3 \mathrm{mg} / \mathrm{dL}$ & $0.1-0.3 \mathrm{mg} / \mathrm{dL}$ \\
\hline Indirect & $0.7 \mathrm{mg} / \mathrm{dL}$ & $0.2-0.7 \mathrm{mg} / \mathrm{dL}$ \\
\hline Glycemia & $110 \mathrm{mg} / \mathrm{dL}$ & $70-115 \mathrm{mg} / \mathrm{dL}$ \\
\hline Cholesterol & $220 \mathrm{mg} / \mathrm{dL}$ & $220-239 \mathrm{mg} / \mathrm{dL}$ \\
\hline LDL & $110 \mathrm{mg} / \mathrm{dL}$ & $<130 \mathrm{mg} / \mathrm{dL}$ \\
\hline HDL & $60 \mathrm{mg} / \mathrm{dL}$ & $>50 \mathrm{mg} / \mathrm{dL}$ \\
\hline Iron & $80 \mu g / d$ & $50-150 \mu \mathrm{g} / \mathrm{d}$ \\
\hline Creatinine & $\mathrm{l} \mathrm{mg} / \mathrm{dL}$ & $0.8-1.2 \mathrm{mg} / \mathrm{dL}$ \\
\hline BUN & $15 \mathrm{mg} / \mathrm{dL}$ & $10-20 \mathrm{mg} / \mathrm{dL}$ \\
\hline Uric acid & $6 \mathrm{mg} / \mathrm{dL}$ & $2.5-8.0 \mathrm{mg} / \mathrm{dL}$ \\
\hline Fibrinogen & $697 \mathrm{mg} / \mathrm{dL}$ & $200-450 \mathrm{mg} / \mathrm{dL}$ \\
\hline Sodium & $140 \mathrm{mEq} / \mathrm{L}$ & |35-145 mEq/L \\
\hline Potassium & $4 \mathrm{mEq} / \mathrm{L}$ & $3.5-5.0 \mathrm{mEq} / \mathrm{L}$ \\
\hline Calcium & $9 \mathrm{mg} / \mathrm{dL}$ & $9-10.5 \mathrm{mg} / \mathrm{dL}$ \\
\hline LDH & $758 \mathrm{U} / \mathrm{L}$ & $100-190 \mathrm{U} / \mathrm{L}$ \\
\hline
\end{tabular}

Abbreviations: RBC, red blood cells; $\mathrm{MCH}$, mean corpuscolar hemoglobin; $\mathrm{MCHC}$, mean corpuscolar hemoglobin concentration; MCV, mean corpuscolar volume; HCT, hematocrit; WBC, white blood cells; N, neutrophils; L, lymphocytes; M, monocytes; E, eosinophils; B, basophils;AST, aspartate tranaminase;ALT, alanine transaminase; LDL, low density lipoproteins; HDL, high density lipoproteins; BUN, blood urea nitrogen; LDH, lactate dehydrogenase; NV, normal values.
Following an abdominal ultrasound imaging (US), a 10-cm right adrenal lesion was identified (Figures 1 and 2). For this reason the patient underwent a total body CT-scan that revealed a 10-cm round, dense, heterogeneous enhancing lesion with irregular margins and inhomogeneous contrast enhancement of solid component after intravenous (iv) contrast medium. Local invasion (right liver lobe, renal hilus, and right diaphragm) and tumor extension into the inferior vena cava, as well as a tumor thrombus in the inferior vena cava and in the pulmonary arteries, were found. After 5 and 7 days, adrenal scintigraphy with iodocholesterol analogs showed a discordant pattern with absence of radiotracer uptake by the adrenal mass.

On the basis of these findings a diagnosis of "right adrenocortical carcinoma hormonally inactive" was made. Due to the invasive nature of the tumor we chose to put the patient on single agent mitotane.

\section{Discussion}

Incidentally discovered adrenal masses are found more frequently, so that all clinicians need to be aware of their etiology since each case needs to be treated individually. Patient age, general conditions, and tumor extension have to be taken into account; they may suggest avoiding combination therapy with other cytotoxic drugs and surgical treatment.

The true prevalence of AIs is unknown. Much of the information quoted is derived from autopsy series, in which the prevalence of undiagnosed adrenal masses ranges from $1.4 \%$ to $3 \%-6 \%{ }^{6}$ These results resemble those emerging from imaging studies, in fact, the prevalence of AIs in daily radiological practice is up to $5 \%$ of CT examination performed for various reasons. ${ }^{7}$

However, the prevalence of incidentally discovered adrenal masses increases with age, accounting for less than $1 \%$ in patients aged younger than 30 years, approximately $7 \%$

Table 2 Endocrine work-up

\begin{tabular}{lll}
\hline & & NV \\
\hline Cortisol & $164.3 \mathrm{ng} / \mathrm{mL}$ & $50-250 \mathrm{ng} / \mathrm{mL}$ \\
Renin & $2 \mathrm{ng} / \mathrm{mL} / \mathrm{h}$ & $0.3-3.0 \mathrm{ng} / \mathrm{ml} / \mathrm{h}$ \\
Aldosteron & $10 \mu \mathrm{gL}$ & $5-19 \mu \mathrm{d} / \mathrm{dL}$ \\
ACTH & $16 \mathrm{pg} / \mathrm{mL}$ & $0-46 \mathrm{pg} / \mathrm{mL}$ \\
Epinephrine & $35 \mu \mathrm{g} / \mathrm{d}$ & $<50 \mu \mathrm{g} / \mathrm{d}$ \\
Norepinephrine & $60 \mu \mathrm{g} / \mathrm{dL}$ & $15-80 \mu \mathrm{g} / \mathrm{dL}$ \\
Overnight & $3 \mu \mathrm{g} / \mathrm{dL}$ & $<5 \mu \mathrm{g} / \mathrm{dL}$ \\
dexamethasone & & \\
suppressor test & & \\
\hline
\end{tabular}

Abbreviations: ACTH, adrenocorticotropic hormone (corticotropin); NV, normal values. 


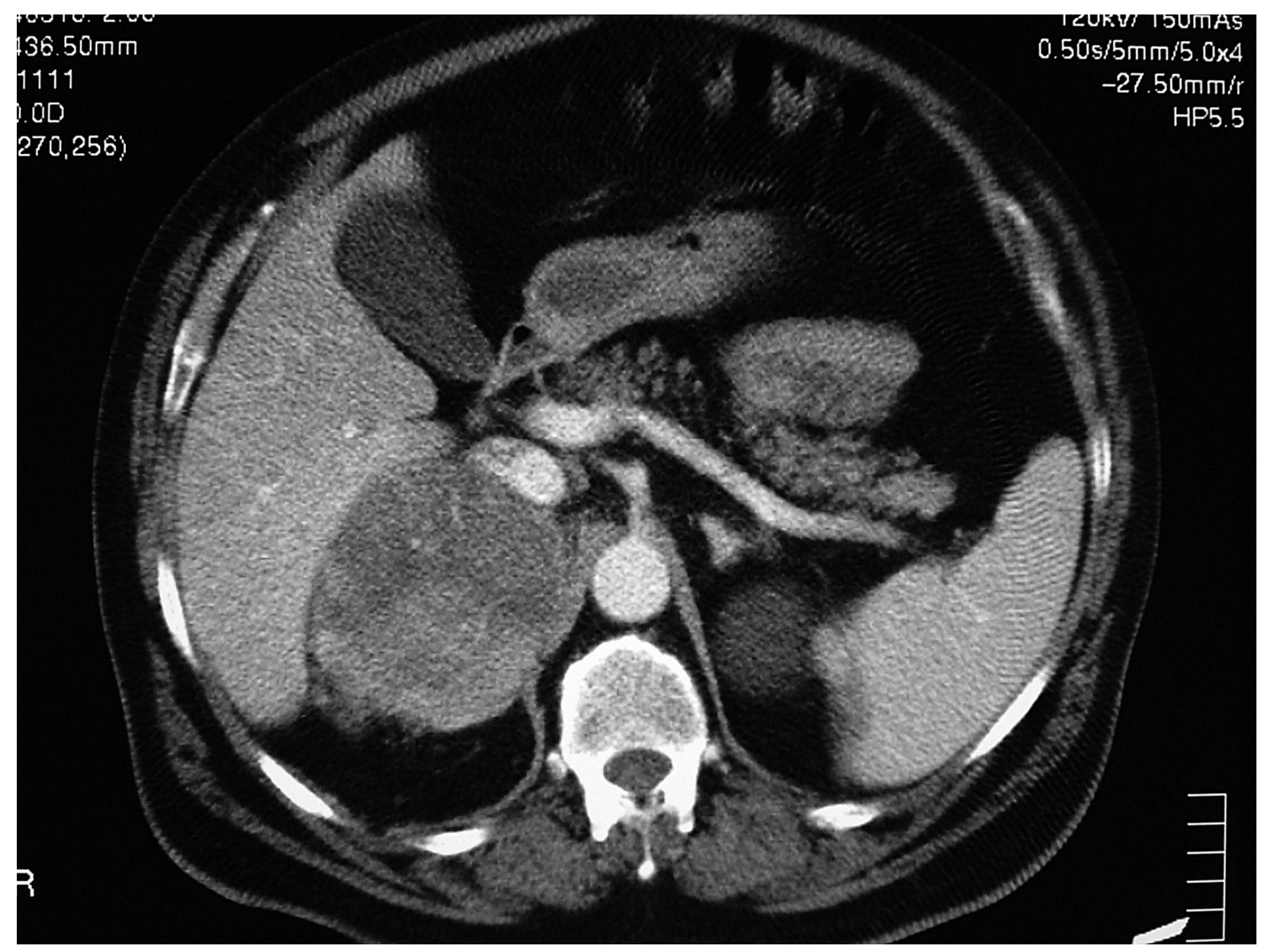

Figure I Abdominal computed tomography shows a 10-cm right adrenal lesion.

between the fifth and the seventh decades, and showing peak incidence in the sixth decade. ${ }^{8}$

$\mathrm{AI}$ is not a single pathological entity. A recent study ${ }^{9}$ on the prevalence of incidental adrenal mass confirmed histologically, shows that adenomas and myelolipomas are the most common lesions, whereas adrenocortical carcinoma is about $0.1 \%$.

ACC is a rare malignancy (incidence 1-2 per million people) and radiologic prevalence is clearly related to the size of the tumor, accounting for $2 \%$ of tumors that are $4 \mathrm{~cm}$ or less, $6 \%$ of tumors that are 4.1 to $6 \mathrm{~cm}$, and $25 \%$ of tumors that are greater than $6 \mathrm{~cm} .{ }^{10}$ Clinical presentation is heterogeneous and prognosis is variable but generally poor, ${ }^{11}$ in fact, overall, this neoplasia accounts for $0.02 \%$ to $0.2 \%$ of all cancer-related deaths, with a median survival of 18 months.

Women are more often affected than men (ratio 1:5); ${ }^{12}$ this gender difference could be partly explained by the higher rate of diagnostic abdominal procedures recommended for women than men. The age distribution has two peaks: the first in childhood and the second in the fourth and fifth decade. ${ }^{13}$

Pathogenesis was incompletely understood, mutation at the $17 \mathrm{p} 13$ locus, including the p53 tumor suppressor gene, is observed in about $25 \%$ of cases $;{ }^{14}$ furthermore, alterations of the 11p15 locus, leading to IGF-II overexpression are frequently observed ${ }^{15}$ compared to adenomas or normal adrenal cortex.

Patients present hormonal excess (virilization in women and gynecomastia and testis atrophy in men), ${ }^{16}$ Cushing's syndrome, or local effect mass in hormonally inactive ACC (nausea, vomiting, abdominal and back pain). ${ }^{17}$

Biochemical screening for tumor hypersecretion as well as imaging evaluation is mandatory in all adrenocortical carcinomas to define the most correct approach. In fact, in stages I-II (localized or locally invasive tumor) complete tumor removal offers the best chance for cure by far, ${ }^{16}$ in particular a complete resection. ${ }^{18}$ In ACC sized more than 


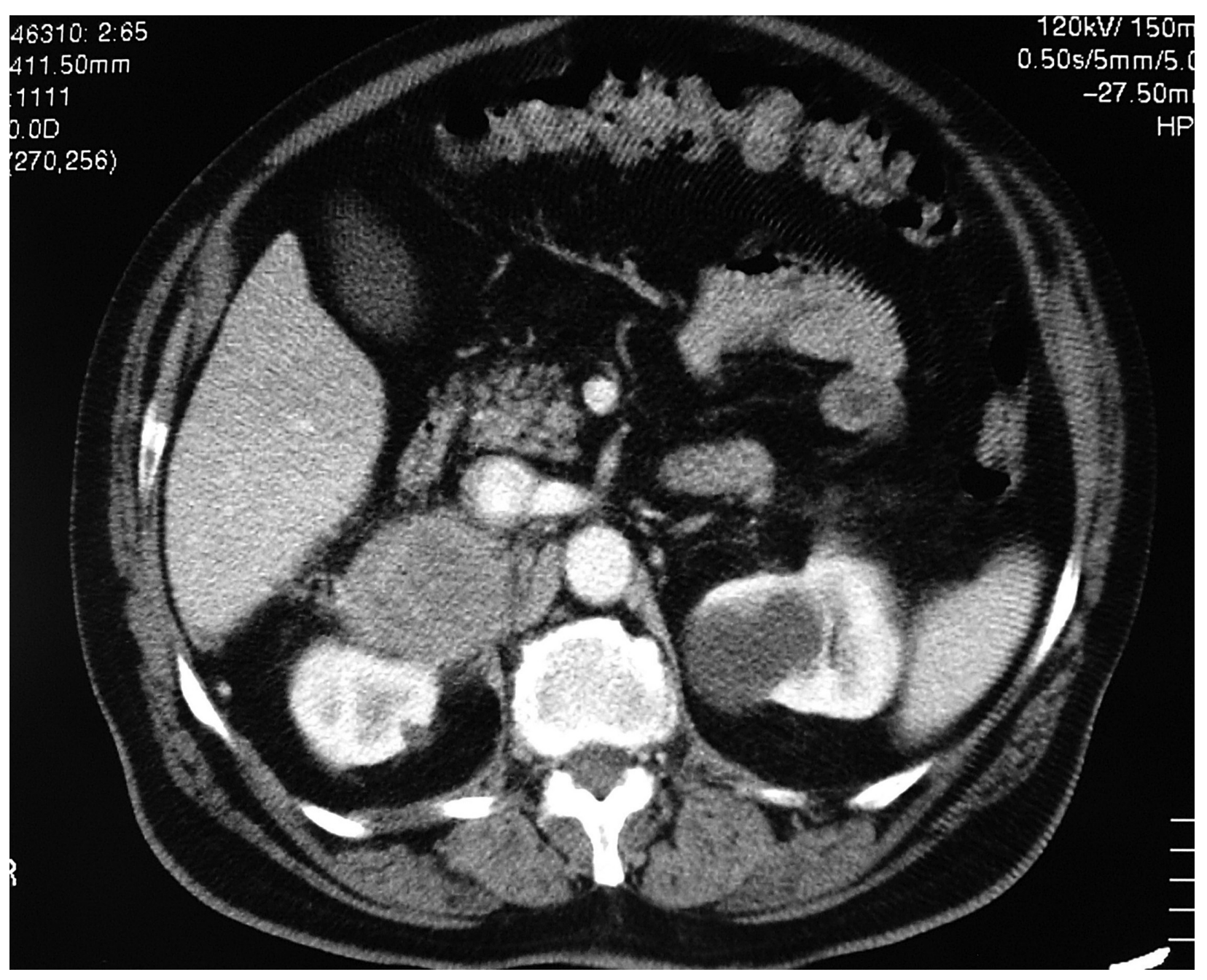

Figure 2 Abdominal computed tomography shows a $10-\mathrm{cm}$ right adrenal lesion.

$10 \mathrm{~cm}$ or with invasion of adjacent organs, local recurrence after surgery occurs in $40 \%$ of patients. ${ }^{19}$

Our patient had an advanced tumor and diagnosis was belated due to the absence of hormonal excess symptoms. Considering our patient's age, general conditions (hypertension, sinus tachycardia, obesity), invasivity and prognosis of the neoplasm, and the possibility of intraoperative complications, even after the negativity of biochemical work up (Table 2), we considered a medical therapy with mitotane.

Although adrenalectomy is the method of choice for the management of patients with ACC, being also compatible with a complete tumor resection in the presence of a tumor thrombus in the inferior vena cava, ${ }^{20}$ medical treatment should be considered as an alternative to adrenalectomy in elderly patients, in those unwilling to undergo surgery, and in patients with comorbid conditions that preclude surgery. ${ }^{21} \mathrm{In}$ fact, while the presence of tumor thrombus may necessitate cardiac bypass technique, the prognosis of ACC still remains poor even after surgery with an overall five-year survival rate ranging between $16 \%$ and $38 \%$ in different series. ${ }^{22}$ Moreover, survival is clearly related to the extent of disease..$^{23}$

Mitotane is the only adrenal-specific agent available for treatment of ACC, it exerts a specific cytotoxic effect on adrenocortical cells producing focal degeneration. In the first study on the efficacy of this therapy by Lim and colleagues, ${ }^{24}$ seven of 18 patients with ACC showed significant tumor regression; even more favorable was the report by Lubitz and colleagues, ${ }^{25}$ which described tumor regression in $61 \%$ of patients. A recent clinical review by Allolio and colleagues 5 that analyzed the efficacy of mitotane treatment in advanced ACC, concluded that mitotane leads to an objective tumor regression in about $25 \%$ of cases.

Although a complete response (or even cure) in patients with advanced ACC is extremely rare, long-term survival has been reported; ${ }^{26}$ in fact our patient is alive and in good clinical conditions six months after surgery. 


\section{Disclosure}

The authors report no conflicts of interest in this work.

\section{References}

1. Alexandraki KI, Grossman AB. Adrenal incidentalomas: the "rule of four". Clin Med. 2008;8:201-204.

2. Prinz RA, Brooks MH, Churchill R, et al. Incidental asymptomatic adrenal masses detected by computed tomographic scanning. Is operation required? JAMA. 1982;248:701-704.

3. Singh PK, Buch HN. Adrenal incidentaloma: evaluation and managment. J Clin Pathol. 2008;61:1168-1173.

4. Grumbach MM, Biller BM, Brownstein GD, et al. Management of the clinically in apparent adrenal mass (incidentaloma). Ann Intern Med. 2003;138:424-429.

5. Allolio B, Fassnacht M. Clinical review: adrenocortical carcinoma: clinical update. J Clin Endocrinol Metab. 2006;91:2027-2037.

6. Mansmann G, Lau J, Balk E, Rothberg M, Miyachi Y, Bornstein SR. The clinically inapparent adrenal mass: update in the diagnosis and management. Endocr Rev. 2004;25:309-340.

7. Kloos RT, Gross MD. Francis IR, Korobkin M, Shapiro B. Incidentally discovered adrenal masses. Endocr Rev. 1995;16:460-484.

8. Barzon L, Boscaro M. Diagnosis and management of adrenal incidentalomas. J Urol. 2000;163:398-407.

9. Song JH, Chaudry FS, Mayo-Smith WW. The incidental adrenal mass on CT: prevalence of adrenal disease in 1,049 consecutive adrenal masses in patients with no known malignancy. AJR Am J Roentgenol. 2008;190:1163-1168.

10. Vierhapper H, Heinze G, Gessl A, Exner M. Adrenocortical tumors; prevalence of impaired glucose tolerance and of "Paradoxical Rise" of cortisol during an oral glucose tolerance test. Exp Clin Endocrinol Diabetes. 2003;111:415-420.

11. Stratakis CA, Chrousos GP. Adrenal cancer. Endocrinol Metab Clin North Am. 2000;29:15-25.

12. Del Gaudio AD, Del Gaudio GA. Virilizing adrenocortical tumors in adult woman. Report of 10 patients, 2 of whom each had a tumor secreting only testosterone. Cancer. 1993;72:1997-2003.
13. Wooten MD, King DK. Adrenal cortical carcinoma. Epidemiology and treatment with mitotane and a review of the literature. Cancer. 1993;72:3145-3155.

14. Reincke M, Karl M, Travis WH, et al. P53 mutations in human adrenocortical neoplasms: Immunohistochemical and molecoular studies. J Clin Endocrinol Metab. 1994;78:790-794.

15. Heppner C, Reincke M, Agarwal SK, et al. MEN1 gene analysis in sporadic adrenocortical neoplasms. J Clin Endocrinol Metab. 1999;84: 216-219.

16. Vassilopoulou-Sellin R, Schultz PN. Adrenocortical carcinoma. Clinical outcome at the end of the 20th century. Cancer. 2001;92:1113-1121.

17. Crucitti F, Bellantone R, Ferrante A, Bischerini M, Crucitti P. The italian registry for adrenal cortical carcinoma: analysis of a multiinstitutional series of 129 patients. The ACC Italian registry study group. Surgery. 1996;119:161-170.

18. Bodie B, Novick AC, Pontes JE, et al. The Cleveland clinic experience with adrenal cortical carcinoma. J Urol. 1989;141:257-260.

19. Porte H, Siat J, Guibert B, et al. Resection of adrenal metastases from non-small cell lung cancer: a multicenter study. Ann Thorac Surg. 2001;71:981-985.

20. Mantero F, Terzolo M, Arnaldi G, et al. A survey on adrenal incidentaloma in Italy. Clin Endocr Metab. 2000;85(2):637-644.

21. Haak HO, Hermans J, van de Velde CJ, et al. Optimal treatment of adrenocortical carcinoma with mitotane: results in a consecutive series of 96 patients. Br J Cancer. 1994;69:947-951.

22. Icard $P$, Goudet $P$, Charpenay $C$, et al. Adrenocortical carcinoma: surgical trends and results of a 253-patient series from the French Association of Endocrine Surgeons Study Group. World J Surg. 2001;25:891-897.

23. Wajchenberg B, Albergaria PM, Medonca B, et al. Adrenocortical carcinoma: clinical and laboratory observations. Cancer. 2000;88:711-736.

24. Lim MC, Tan YO, Chong PY, Cheah JS. Treatment of adrenal cortical carcinoma with mitotane: outcome and complications. Ann Acad Med Singapore. 1990;19:540-544.

25. Lubitz JA, Freeman L, Okun R. Mitotane use in inoperable adrenal cortical carcinoma. JAMA. 1973;223:1109-1112.

26. Allolio B, Hahner S, Weismann D, Fassnacht M. Management of adrenocortical carcinoma. Clin Endocrinol (Oxf). 2004;60:273-287.
Clinical Interventions in Aging

\section{Publish your work in this journal}

Clinical Interventions in Aging is an international, peer-reviewed journal focusing on evidence-based reports on the value or lack thereof of treatments intended to prevent or delay the onset of maladaptive correlates of aging in human beings. This journal is indexed on PubMed Central, MedLine, the American Chemical Society's 'Chemical

\section{Dovepress}

Abstracts Service' (CAS), Scopus and the Elsevier Bibliographic databases. The manuscript management system is completely online and includes a very quick and fair peer-review system, which is all easy to use. Visit http://www.dovepress.com/testimonials.php to read real quotes from published authors. 